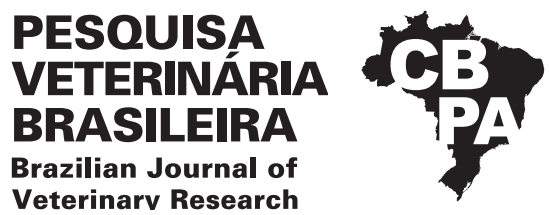

\title{
Adiposity and weight gain in Mangalarga Marchador horses subjected to hypercaloric $\operatorname{diet}^{1}$
}

\author{
Rodrigo M. Ribeiro² (D), Debora S.F. Ribeiro², Cahue F.R. Paz ${ }^{2}$, \\ Alexandre A.O. Gobesso ${ }^{3}$ and Rafael R. Faleiros ${ }^{2,4 *}$ (D)
}

\begin{abstract}
Ribeiro R.M., Ribeiro D.S.F., Paz C.F.R., Gobesso A.A.O. \& Faleiros R.R. 2020. Adiposity and weight gain in Mangalarga Marchador horses subjected to hypercaloric diet. Pesquisa Veterinária Brasileira 40(3):170-175. Graduate Program in Animal Science, Escola de Veterinária, Universidade Federal de Minas Gerais, Av. Antônio Carlos 6627, Cx. Postal 567, Campus Pampulha, Belo Horizonte, MG 31270-901, Brazil. E-mail: faleirosufmg@gmail.com

In recent years, several researchers have been studying obesity in national horse breeds; however, no studies demonstrating the dynamic of body and regional fat accumulation (adiposity) Mangalarga Marchador horses subjected to hypercaloric diets have been found. This study aimed to characterize the deposition of body and regional fat in horses with diet-induced weight gain. A total of nine Mangalarga Marchador adult horses with initial body condition score (BCS) of $2.9 \pm 1 / 9$ (mean \pm SD) were subjected to a hypercaloric, grainrich diet for five months. Body weight and the following morphometric regional adiposity variables were analyzed: BCS, cresty neck scores (CNS), neck circumferences (NC) at 25, 50 and $75 \%$ of its length, and accumulation of subcutaneous adipose tissue at the base of the tail using ultrasonography (BTU). These data were collected at baseline and fortnightly after beginning the diet-induced weight gain until the end of the experiment. The effect of time on the variables was verified by analysis of variance (ANOVA) in randomized blocks or the Friedman's test, and the means were compared by the Tukey's test $(p \leq 0.05)$. Exposure to hypercaloric diet promoted a mean weight gain of $27.45 \%(p<0.001)$. Significant values were observed for NC at 25 and $75 \%$ during the first 45 days of the experiment, and for NC at $50 \%$ during the first 30 days. BTU presented significant changes after 60 days, with an increase of $268 \%$ compared with the baseline value. These findings demonstrate the weight gain and the dynamic and magnitude of regional adiposity in Mangalarga Marchador horses subjected to hypercaloric diet.
\end{abstract}

INDEX TERMS: Adiposity, weight gain, Mangalarga Marchador, equine, hypercaloric diet, metabolic syndrome, regional fat, horses.

RESUMO.- [Adiposidade e ganho de peso em equinos Mangalarga Marchador submetidos a dieta hipercalórica.] Nos últimos anos vários pesquisadores têm estudado obesidade

\footnotetext{
${ }^{1}$ Received on August 31, 2019.

Accepted for publication on September 4, 2019.

Doctoral research with financial support from CAPES and FAPEMIG.

${ }^{2}$ Equinova Research Group, Graduate Studies Program in Animal Science, Escola de Veterinária, Universidade Federal de Minas Gerais (UFMG), Av. Antônio Carlos 6627, Cx. Postal 567, Campus Pampulha, Belo Horizonte, MG 31270-901, Brazil. *Corresponding author: faleirosufmg@gmail.com

${ }^{3}$ Graduate Studies Program in Nutrition and Animal Production (PPGNPA), Faculdade de Medicina Veterinária e Zootecnia, Universidade de São Paulo (USP), Rua da Reitoria 374, 4o andar, Butantã, São Paulo, SP 05508-220, Brazil.

${ }^{4} \mathrm{CNPq}$ and FAPEMIG researcher, Universidade Federal de Minas Gerais (UFMG), Av. Antônio Carlos 6627, Cx. Postal 567, Campus Pampulha, Belo Horizonte, MG 31270-901, Brazil.
}

em raças nacionais, contudo não se encontram estudos que demonstrem a dinâmica do acúmulo de gordura corporal e regional em equinos marchadores submetidos a dietas hipercalóricas. 0 objetivo deste trabalho foi caracterizar a deposição de gordura corporal e regional em equinos com obesidade induzida. Foram utilizados nove equinos adultos, Mangalarga Marchador com escore de condição corporal (ECC) inicial de 2,9 $\pm 1 / 9$ (média \pm DP) submetidos a dieta hipercalórica por 5 meses. Foram avaliados o peso corporal, e as variáveis de adiposidade como o ECC, escore de acúmulo de gordura na crista de pescoço (ECP), circunferência do pescoço a $25 \%$, $50 \%$ e $75 \%$ de seu comprimento e o acúmulo de gordura subcutânea na base da cauda por ultrassonografia (UBC). Coletados antes do início do experimento e quinzenalmente após o início da indução do ganho de peso. 0 efeito do tempo 
sobre as variáveis foi verificado por análise de variância em blocos ao acaso ou teste de Friedman e as médias foram comparadas pelo teste de Tukey $(\mathrm{P} \leq 0,05)$. 0 tratamento promoveu aumento médio de peso de $27,45 \%(\mathrm{P}<0,001)$. Já as circunferências de pescoço $25 \%$ e $75 \%$ apresentaram valores significativos nos 45 dias de experimento e a circunferência a $50 \%$ se destacou nos primeiros 30 dias. A UBC apresentou alterações significativas aos 60 dias de experimento, com um acréscimo de $268 \%$ em relação ao valor basal. Tais achados demonstram o ganho de peso, a dinâmica e a magnitude do acúmulo de gordura localizada em equinos Mangalarga Marchador submetidos à dieta hipercalórica.

TERMOS DE INDEXAÇÃO: Adiposidade, ganho de peso, equinos, Mangalarga Marchador, dieta hipercalórica, síndrome metabólica, gordura regional.

\section{INTRODUCTION}

According to the World Health Organization (WHO), overweight and obesity are defined as abnormal or excessive fat accumulation that presents a risk to health (Geor 2008). In developed countries, prevalence of obesity is estimated at approximately 19-40\% in horse populations (Wyse et al. 2008, Thatcher et al. 2012). To demonstrate how commonly obesity occurs in this species, a study evaluating 300 adult animals found that $19 \%$ of them were obese (body condition score (BCS) between 8 and 9) and 32\% were overweight (BCS from 6.5 to 7.5 ) (Allan et al. 2000). Another study observed that $45 \%$ of the horses in a population of 319 randomly selected animals were obese or very obese (Robertson 2003).

Obesity is induced with the provision of high grain and forage diets (grass and hay) with high non-structural carbohydrate (NSC) contents, becoming a consequence of overfeeding, leading to excessive fat reserves in relation to body demand and the level of physical activity (Schott et al. 2001, Johnson 2002).

Fat accumulation (adiposity) can trigger exercise intolerance, thermoregulatory inefficiency, abnormal reproductive performance, and increased likelihood of developing mesenteric lipomas (Henneke et al. 1984, Cymbaluk \& Christison 1990, Garlinghouse \& Burrill 1999, Garcia-Seco et al. 2005). In addition to these changes, obesity is closely related to equine metabolic syndrome (EMS) and insulin dysregulation (ID) (Frank et al. 2010).

Several studies have shown that regional adiposity is closely correlated with ID, hyperinsulinemia and metabolic disorders such as dyslipidemia, high levels of leptin and nonesterified fatty acids, increased proinflammatory cytokine gene expression, high peripheral blood protein concentrations, and increased risk of developing laminitis (Johnson 2002, Sutherland et al. 2004, Vick et al. 2007, 2008, Carter et al. 2009). Thus, adipocytes located in different parts of the organism present different characteristics, and some adipocytes secrete endocrine signaling that can lead to metabolic dysfunction (Chaldakov et al. 2003, Lyon et al. 2003).

A relationship between obesity and evidence of metabolic disease in Brazilian horses has been confirmed by several studies (Paz et al. 2013, Magalhães et al. 2014, 2017, Xavier et al. 2014). However, the magnitude and dynamic of adiposity in national fattening horses are not yet known. The objective of this experiment was to characterize body and regional adiposity in Mangalarga Marchador horses with diet-induced weight gain.

\section{MATERIALS AND METHODS}

Nine healthy Mangalarga Marchador horses (five non-pregnant mares and four geldings) aged $48 \pm 5$ months with initial weight of $316 \pm 62.68 \mathrm{~kg}$ were used in this study. For standardization of diet administration, the horses were housed in duly identified individual stalls with sawdust-covered floor and access to water ad libitum. The experiment was carried out at the facilities of "Fazenda Modelo Pedro Leopoldo" of the "Universidade Federal deMinas Gerais" (UFMG).

Obesity was induced through provision of digestible energy (DE) in amounts 100\% higher than the maintenance requirement established in the reference literature (NRC 2007). Digestible energy maintenance (DEm) was calculated based on the mathematical formula $\mathrm{DE}=1.4+(0.03 \mathrm{x} \mathrm{Kg}$ live weight $[\mathrm{LW}])$, according to the NRC (2007), over a period of 150 days.

In order to avoid gastrointestinal disorders, it was previously established that animals would receive DEm once in concentrate form and once the forage form. To this end, the DE values for the feed available were used: commercial concentrate (Guabi Equitage Laminados) (DE: $3.650 \mathrm{Mcal} / \mathrm{kg}$ ) and grass hay Cynodon dactylon (L.) Pers.Var. Coast cross (DE: $2.0 \mathrm{Mcal} / \mathrm{kg}$ ). Thus, the amounts of forage and concentrate were calculated considering the DEm of each animal divided by the DE concentration of each type of feed: Amount of Concentrate $(\mathrm{kg}): \mathrm{DE}=(1.4+(0.03 \times \mathrm{kg} \mathrm{LW})) / 3.650$; Bulk Amount (kg): DE $=(1.4+(0.03 \times \mathrm{kg} \mathrm{LW})) / 2$.

This calculation was repeated fortnightly after the animal weight was measured, thus maintaining the proportion of $100 \%$ on the DE requirement established by the NRC (2007) constant over the 150 days of the trial period. The diet was provided in individual feeders, in three (3) daily meals and equal parts offered at 6am, $12 \mathrm{pm}$, and $18 \mathrm{pm}$.

At baseline and fortnightly after beginning the diet-induced weight gain until the end of the experiment, the animals were evaluated walking and trotting to detect absence/presence of lameness. A sensitivity test was also performed using the hoof testers at baseline and at 30-day intervals until the end of the experiment.

Body weight and the following morphometric regional adiposity variables were assessed at baseline and fortnightly until the end of the experiment: body condition score (BCS), cresty neck score (CNS), and neck circumference (NC). To measure the BCS of the horses, a scale ranging from 1 to $9(1=$ emaciated and $9=$ extremely obese) was used according to the grading proposed by Henneke et al. (1984). The CNS, which indicates metabolic disease, was verified using a 5-point scale $(0=$ crest not visible and not palpable and 5 = increased crest permanently drooping to one side), according to Carter et al. (2009).

Accumulation of subcutaneous adipose tissue at the base of the tail using ultrasonography (BTU) was measured at baseline and every 30 days until the end of the experiment.

A weighing scale was used to measure the body weight of the animals. For objective assessment of local fat deposition, neck circumference (NC) measurements were performed at three different points at the total neck length, according methodology described by Frank et al. (2006). These measurements were performed at dorsal points corresponding to 25,50 , and $75 \%$ of the neck length. The BTU measurements were obtained using an ultrasound device (Echovet, model KX 5100) equipped with a $5 \mathrm{MHz}$ transducer, which was positioned on the right side of the base of the tail, $5 \mathrm{~cm}$ away 
from the midline (Fig.1), according to the methodology described by Gentry et al. (2004).

For statistical analysis, the data were processed using the Sigma (SigmaStat, Systat) computer software. The effect of time on the variables with normal distribution was verified by analysis of variance (ANOVA) in randomized blocks, followed by the Tukey's test for comparison between the means. For the nonparametric data of the BCS and NC variables, repeated measures ANOVA over

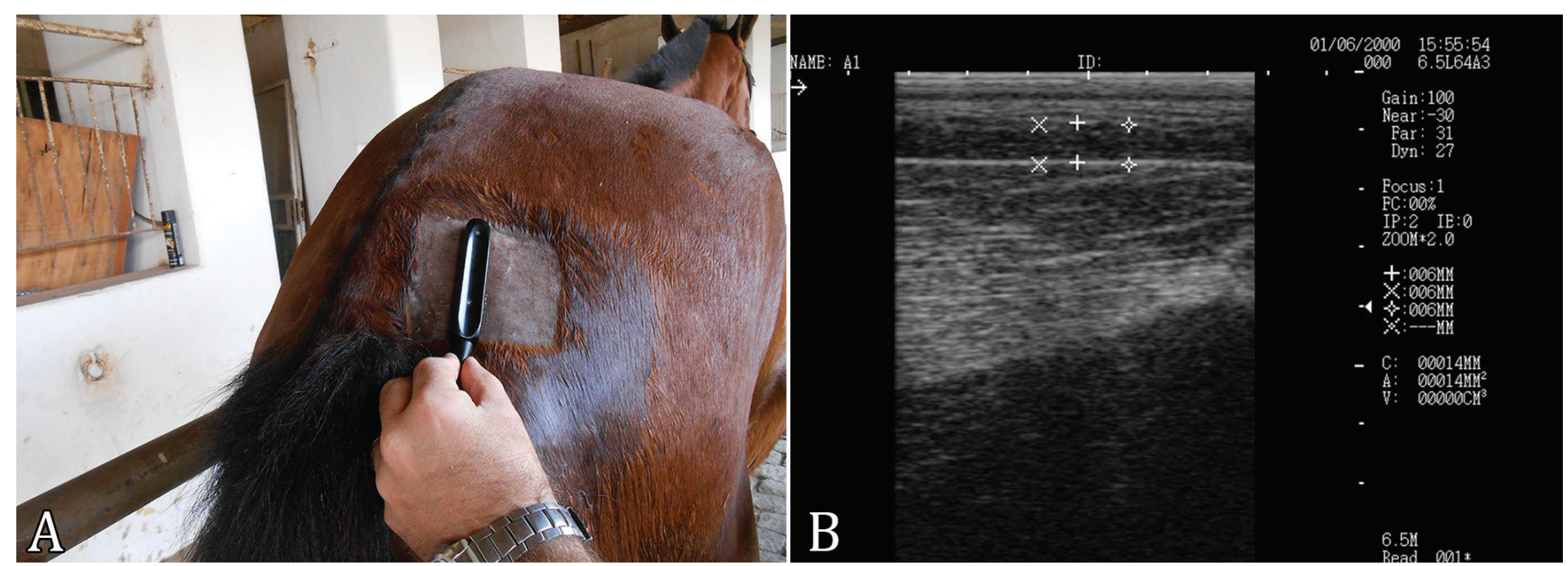

Fig.1. Procedure used to measure accumulation of subcutaneous adipose tissue at the base of the tail by ultrasonography (BTU). (A) Demonstration of transducer location of the ultrasound device. (B) Demonstration of the image obtained by an ultrasound device measuring three areas of the subcutaneous fat layer.
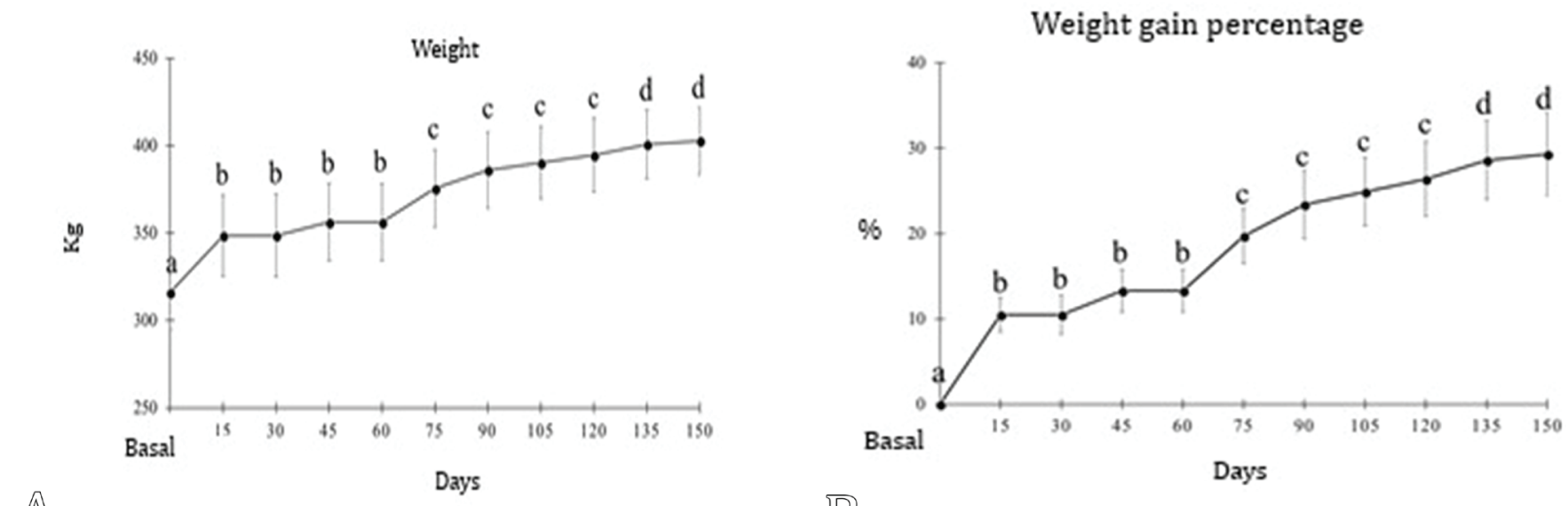

$\widehat{\Delta}$

D

Body condition score
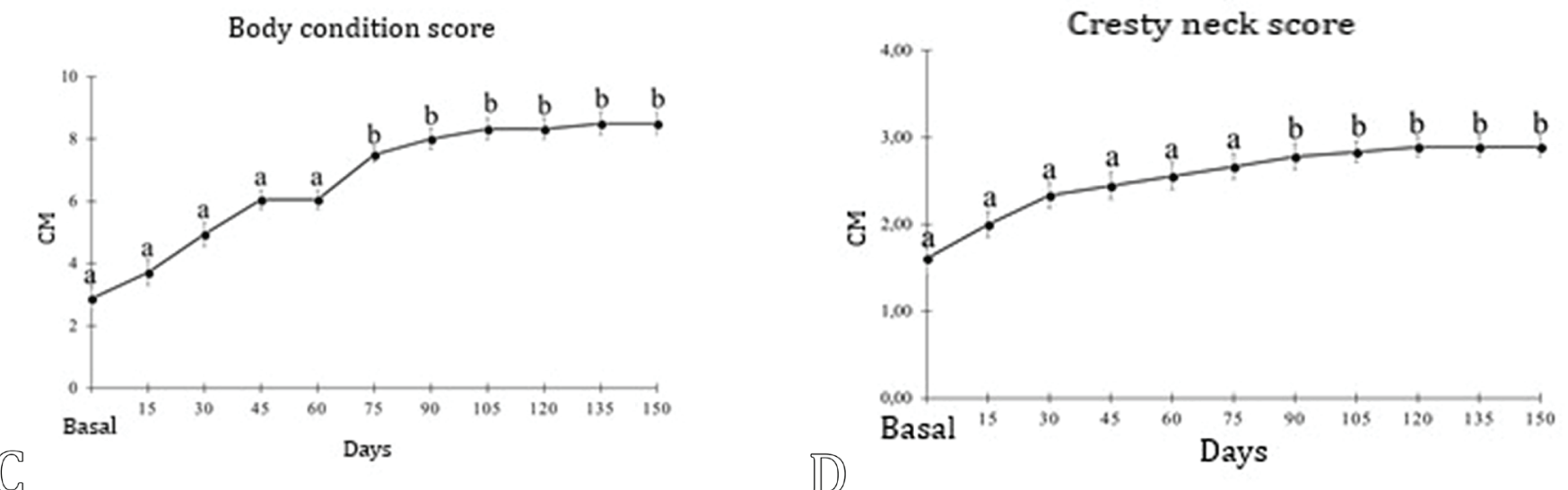

Fig.2. (A) Means and standard errors for weight gain, (B) weight gain percentage, (C) body condition score (BCS), and (D) cresty neck score (CNS) of Mangalarga Marchador horses subjected to hypercaloric diet. Means followed by the same letters do not differ by the Tukey's test for parametric variables and by the Friedman's test for nonparametric variables, at $5 \%$ probability. 
time and the Friedman's test were used. A significance level of 5\% $(p \leq 0.05)$ was adopted for all statistical analyses.

\section{RESULTS}

During the experimental period, the horses consumed a daily average of $0.94 \pm 0.02 \%$ of concentrate and $1.72 \pm 0.04 \%$ of forage of body weight. There were no colic event, evidence of lameness, or signs of sensitivity by hoof tester exam.At the end of the experiment, the animals presented an average weight gain of $27.45 \%$, with significant values $(p<0.001)$ as of the second measurement (Fig.2). BCS and NC showed significant increases at 75 and 90 days, respectively (Fig.2), NC at 25 and $75 \%$ showed significant increases at 45 days, and NC at $50 \%$ present significant increase at 30 days (Fig.3). The BTU values showed significant alterations after 60 days, with an increase of $268 \%$ compared with the baseline value (Fig.3).

\section{DISCUSSION}

In the present study, it was possible to verify the effects of hypercaloric diet on the body weight and regional fat accumulation in Mangalarga Marchador horses. During the experimental period, the animals presented a weight gain of $27.5 \%$ compared with the initial values. As they were animals in the end of the developmental phase, this weight gain was reflected in the accumulation of subcutaneous adipose tissue promoting a 2.95-fold increase in BCS and a 1.7-fold increase in CNS.

It is known that the use of scores for the determination of adiposity in horses presents great individual variation, even when conducted by trained professionals (Young et al. 2004, Mottet et al. 2009). As noted by other authors, BCS is not accurate to assess regional fat accumulation because these adipose deposits often occur asymmetrically, hindering determination of the actual body situation of the animal (Geor 2008). However, these methods continue to be used in practice because they present significant correlations with metabolic disorders such as ID (Carter et al. 2007).

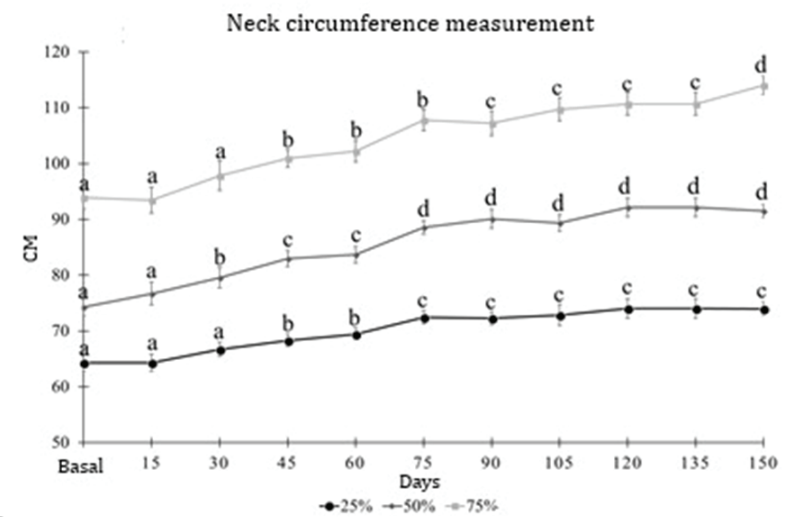

A

Fig.3. (A) Means and standard error for neck circumference (NC) measured at 25, 50 and 75\% of the distance between the nape and the withers and (B) accumulation of subcutaneous adipose tissue at the base of the tail using of ultrasonography (BTU) of Mangalarga Marchador horses subjected to hypercaloric diet. Means followed by the same letters do not differ from each other by the Tukey's test, at $5 \%$ probability.
Objective methods, such as NC and BTU, were also used. Increases of 15, 23 and 21\%, respectively, in circumference measures taken at 25,50 and $75 \%$ of the neck length were observed. A study conducted by Frank et al. (2006) showed that neck circumference correlated closely with the area under the insulin curve, which is a well known risk factor for the development of insulin resistance (IR) in horses. All NC measures showed an increase throughout the experiment, proving that the use of NC is an objectively valid for the evaluation of regional fat accumulation. However, of these three measurements, NC at 50\% was the one that presented the largest increase, being evidenced as the variable that stands out to measure animal weight gain, corroborating studies addressing Mangalarga Marchador (Lima et al. 2010) and police (Xavier et al. 2014) horses.

The BTU method should be highlighted in this study, because it directly determined subcutaneous fat deposition and presented a 7-fold increase from baseline. BTU has also proved to be a sensitive alternative to the early signaling of regional fat accumulation, presenting significant values after 60 days. The use of ultrasonography is effective in identifying regional accumulation of subcutaneous adipose tissue in horses and other farm animals (Westervelt et al. 1976, Gee et al. 2003, Dugdale et al. 2010, Silva \& Cadavez 2012). Françoso et al. (2012) concluded that measuring subcutaneous fat at the base of the tail is the most reliable method to estimate adiposity, in agreement with the findings by Gentry et al. (2004), who reported that the tail region is where the most substantial fat deposition occurs in the body of a horse.

Changes in some biomarkers have been found to correlate with regional adiposity markers independently. This feature can be explained by a theory that defends that adipose tissue displays notably different effects depending on its location in the body. It has been theorized that adipocytes have different characteristics depending on their location (Lyon et al. 2003).

In this context, several authors have proposed that fat accumulation in some areas of equine subcutaneous tissue is responsible for the development of EMS. For example, accumulation of fat in the neck is associated with higher

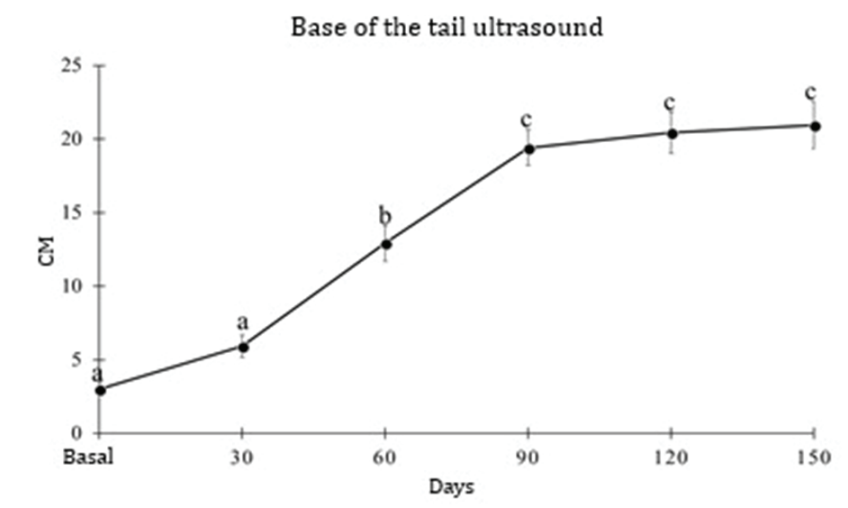

D) 
expression of the IL- $1 \beta$ and IL- 6 genes, whereas visceral fat is linked to a larger number of active macrophages and a larger amount of leptin (De Luca \& Olefsky 2008, Vick et al. 2008, Burns et al. 2010, Maury \& Brichard 2010, Weber et al. 2013).

Increased adiposity on the neck and NC are closely correlated with IR. Packer et al. (2011) observed correlation between retro abdominal fat accumulation and leptin gene expression in horses, and Xavier et al. (2014) found correlation between BTU and BCS with radiographic alterations consistent with the spatial changes of the third phalanx.

Other studies have observed that adiposity parameters such as CNS, NC, BTU, weight gain, and BCS were positively correlated with metabolic changes and changes observed in the laminar tissue of horses, evidencing the value of the present work, considering that the horses used presented distribution of fat accumulation in the aforementioned places (Ribeiro et al. 2015a, 2015b, 2016). These measurements can assist with the monitoring of weight gain, and these obesity parameters can be used as reference to demonstrate whether the animals are presenting regional adiposity, thus being predisposed to possible metabolic changes.

\section{CONCLUSION}

Exposure to hypercaloric diet promoted weight gain and body fat deposition, with emphasis on body condition score (BCS), neck circumference (NC), and subcutaneous thickness at the base of the tail using ultrasonography (BTU). These findings demonstrated that these variables can be useful to monitor total and regional fat deposition in Mangalarga Marchador horses.

Acknowledgments.- The authors are grateful to "Conselho Nacional de Desenvolvimento Científico e Tecnológico" (CNPq), "Coordenação de Aperfeiçoamento de Pessoal de Nível Superior" (CAPES), and "Fundação de Amparo à Pesquisa do Estado de Minas Gerais" (FAPEMIG) for financial support.

Ethics and biosafety committee.- CEUA-UFMG protocol no. 49/2014.

Conflict of interest.- The authors have no conflicts of interest to declare.

\section{REFERENCES}

Allan F.J., Pfeiffer D.U., Jones B.R., Esslemont D.H.B. \& Wiseman M.S. 2000. A cross-sectional study of risk factors for obesity in cats in New Zealand. Prev. Vet. Med. 46(3):183-196. <http://dx.doi.org/10.1016/s01675877(00)00147-1><PMid:10913803>

Burns T.A., Geor R.J., Mudge M.C., McCutcheon L.J., Hinchcliff K. W. \& Belknap J.K. 2010. Proinflammatory cytokine and chemokine gene expression profiles in subcutaneous and visceral adipose tissue depots of insulin-resistant and insulin-sensitive light breed horses. J. Vet. Int. Med. 24(4):932-939. <http://dx.doi.org/10.1111/j.1939-1676.2010.0551.x><PMid:20649750>

Carter R.A., Geor R.J., Staniar W B., Cubitt T.A. \& Harris P.A. 2009. Apparent adiposity assessed by standardised scoring systems and morphometric measurements in horses and ponies. Vet. J. 179(2):204-210. <http://dx.doi. org/10.1016/j.tvjl.2008.02.029><PMid:18440844>

Carter R.A., Treiber K.H., Harris P.A. \& Geor R.J. 2007. Evaluation of criteria for pre-laminitic metabolic syndrome. Proc. Equine Sci. Soc. 139-141.

Chaldakov G.N., Stankulov I.S., Hristova M. \& Ghenev P.I. 2003. Adipobiology of disease: adipokines and adipokine-targeted pharmacology. Curr. Pharm. Des. 9(12):1023-1031. <http://dx.doi.org/10.2174/1381612033455152> $<$ PMid:12678860>
Cymbaluk N.F. \& Christison G.I. 1990. Environmental effects on thermoregulation and nutrition of horses. Vet. Clin. N. Am., Equine Pract. 6(2):355-372. <http://dx.doi.org/10.1016/s0749-0739(17)30546-1><PMid:2202497>

De Luca C. \& Olefsky J.M. 2008. Inflammation and insulin resistance. FEBS Letters 582(1):97-105. <http://dx.doi.org/10.1016/j.febslet.2007.11.057> <PMid:18053812>

Dugdale A.H.A., Curtis G.C., Cripps P., Harris P.A. \& Argo C.M. 2010. Effect of dietary restriction on body condition, composition and welfare of overweight and obese pony mares. Equine Vet. J. 42(7):600-610.<http:// dx.doi.org/10.1111/j.2042-3306.2010.00110.x> <PMid:20840575>

Françoso R., Martins R.A., Gonzaga I.V., Centini T.N., Gil P.C., Baldi F. \& Gobesso A.A. 2012. Avaliação do escore corporal em equinos por meio da ultrassonografia. Revta Educ. Cont. Vet. Med. Zootec. 10(1):78-78.

Frank N., Elliott S.B., Brandt L.E. \& Keisler D.H. 2006. Physical characteristics, blood hormone concentrations, and plasma lipid concentrations in obese horses with insulin resistance. J. Am. Vet. Med. Assoc. 228(9):1383-1390. <http://dx.doi.org/10.2460/javma.228.9.1383> <PMid:16649943>

Frank N., Geor R.J., Bailey S.R., Durham A.E. \& Johnson P.J. 2010. Equine metabolic syndrome. J. Vet. Int. Med. 24(3):467-475. <http://dx.doi. org/10.1111/j.1939-1676.2010.0503.x> <PMid:20384947>

Garcia-Seco E., Wilson D.A., Kramer J., Keegan K.G., Branson K.R., Johnson P.J. \& Tyler J.W. 2005. Prevalence and risk factors associated with outcome of surgical removal of pedunculated lipomas in horses: 102 cases (1987-2002). J. Am. Vet. Med. Assoc. 226(9):1529-1537. <http://dx.doi.org/10.2460/ javma.2005.226.1529><PMid:15882006>

Garlinghouse S.E. \& Burrill M.J. 1999. Relationship of body condition score to completion rate during $160 \mathrm{~km}$ endurance races. Equine Vet. J. 30 (supl.30):591-595. <http://dx.doi.org/10.1111/j.2042-3306.1999. tb05290.x><PMid:10659324>

Gee E.K., Fennessy P.F., Morel P.C.H., Grace N.D., Firth E.C. \& Mogg T.D. 2003. Chemical body composition of 20 Thoroughbred foals at 160 days of age, and preliminary investigation of techniques used to predict body fatness. N. Z. Vet. J. 51(3):125-131. <http://dx.doi.org/10.1080/00480169.2003 .36351><PMid:16032311>

Gentry L.R., Thompson D.L., Gentry G.T., Del Vecchio R.P., Davis K.A. \& Del Vecchio P.M. 2004. The relationship between body condition score and ultrasonic fat measurements in mares of high versus low body condition. J. Equine Vet. Sci. 24(5):198-203. <http://dx.doi.org/10.1016/j.jevs.2004.04.009>

Geor R.J. 2008. Metabolic predispositions to laminitis in horses and ponies: obesity, insulin resistance and metabolic syndromes. J. Equine Vet. Sci. 28(12):753-759. <http://dx.doi.org/10.1016/j.jevs.2008.10.016>

Henneke D.R., Potter G. \& Kreider J.L. 1984. Body condition during pregnancy and lactation and reproductive efficiency of mares. Theriogenology 21(6):897-909. <http://dx.doi.org/10.1016/0093-691X(84)90383-2>

Johnson P.J. 2002. The equine metabolic syndrome peripheral Cushing's syndrome. Vet. Clin. N. Am., Equine Pract. 18(2):271-293. <http://dx.doi. org/10.1016/s0749-0739(02)00006-8> <PMid:15635908>

Lima I., Lima L. \& Varella J. 2010. Diferentes métodos de avaliação da adiposidade em éguas da raça Mangalarga Machador. VI Conferência Anual da Abraveq, Vol. 6, Abraveq, São Paulo, p.203-203.

Lyon C.J., Law R.E. \& Hsueh W. A. 2003. Minireview: adiposity, inflammation, and atherogenesis. Endocrinology 144(6):2195-2200. <http://dx.doi. org/10.1210/en.2003-0285><PMid:12746274>

Magalhães J.F., Lima I.R., Lima L.R., Varela J.A.R.C., Vieira R.A.M., Alves G.E.S. \& Faleiros R.R. 2014. Estudo da correlação de medidas radiográficas indicadoras de laminite em éguas da raça Mangalarga Marchador com e sem sinais de sobrepeso. Arq. Bras. Med. Vet. Zootec. 66(4):1023-1032. <http://dx.doi.org/10.1590/1678-6544>

Magalhães J.F., Lima L.R., Paz C.F., Junior S.S.R., Oliveira Á.P., Duarte P.C. \& Faleiros R.R. 2017. Relação espacial entre a falange distal e o estojo córneo em éguas Campolinas jovens com e sem sinais de obesidade. 
Pesq. Vet. Bras. 37(9):1025-1031. <http://dx.doi.org/10.1590/s0100736x2017000900019>

Maury E. \& Brichard S.M. 2010. Adipokine dysregulation, adipose tissue inflammation and metabolic syndrome. Mol. Cell. Endocrinol. 314(1):116. <http://dx.doi.org/10.1016/j.mce.2009.07.031><PMid:19682539>

Mottet R., Onan G. \& Hiney K. 2009. Revisiting the Henneke body condition scoring system: 25 years later. J. Equine Vet. Sci. 29(5):417-418. <http:// dx.doi.org/10.1016/j.jevs.2009.04.116>

NRC 2007. Nutrient Requirements of Horses. 6th ed. National Research Council of the National Academies, Washington, D.C. 360p.

Packer M.J., German A.J., Hunter L., Trayhurn P. \& Proudman C.J. 2011. Adipose tissue-derived adiponectin expression is significantly associated with increased post-operative mortality in horses undergoing emergency abdominal surgery. Equine Vet. J. 43:26-33. <http://dx.doi. org/10.1111/j.2042-3306.2011.00404.x> <PMid:21790751>

Paz C.F.R., Paganela J.C., Dos Santos C.A., Nogueira C.E.W. \& Faleiros R.R. 2013. Relação entre obesidade, insulina plasmática e posicionamento da falange distal em equinos da raça crioula. Arq. Bras. Med. Vet. Zootec. 65(6):16991705. <http://dx.doi.org/10.1590/S0102-09352013000600017>

Ribeiro R.M., Azevedo D.S.D., Ribeiro D.S.F., Paz C.F.R., Cota L.O. \& Faleiros R.R. 2015a. Correlações entre parâmetros de adiposidade e biomarcadores de disfunção metabólica em equinos com obesidade induzida. Anais XVI Conferência Anual da Abraveq, Águas de Lindóia, SP, p.157. (Resumo)

Ribeiro R.M., Azevedo D.S.D., Ribeiro D.S.F., Paz C.F.R., Cota L.O. \& Faleiros R.R. 2015b. Correlations among adiposity, metabolic dearrangment biomarkers and spatial changes in distal phalangx in horses subjected to hypercaloric diet. Proceedings Equine Cushings and Insulin Resistance Group Inc., Georgetown, TX, p.50. (Resumo)

Ribeiro R.M., Azevedo D.S.D., Ribeiro D.S.F., Paz C.F.R., Cota L.O. \& Faleiros R.R. 2016. Correlações entre parâmetros de adiposidade e análise histopatológica do tecido lamelar em equinos com obesidade induzida. Anais XVII Conferência Anual da Abraveq, Campos de Jordão, SP, p.236. (Resumo)

Robertson I.D. 2003. The association of exercise, diet and other factors with owner-perceived obesity in privately owned dogs from metropolitan Perth, WA. Prev. Vet. Med. 58(1/2):75-83. <http://dx.doi.org/10.1016/ s0167-5877(03)00009-6><PMid:12628772>

Schott H.C., Coursen C.L., Eberhart S.W., Nachreiner R.J., Refsal K.R., Ewart S.L. \& Marteniuk J. 2001. The Michigan Cushing's Project. Proceedings 47th Annual Annual Convention of the American Association of Equine Practitioners, p.22-24.
Silva S.R. \& Cadavez V.P. 2012. Real-time ultrasound (RTU) imaging methods for quality control of meats, p.277-329. In: Sun D.-W. (Ed.), Computer Vision Technology in the Food and Beverage Industries. Woodhead Publishing, U.K.

Sutherland J.P., McKinley B. \& Eckel R.H. 2004. The metabolic syndrome and inflammation. Metab. Syndr. Relat. Disord. 2(2):82-104. <http://dx.doi. org/10.1089/met.2004.2.82><PMid:18370640>

Thatcher C.D., Pleasant R.S., Geor R.J. \& Elvinger F. 2012. Prevalence of overconditioning in mature horses in Southwest Virginia during the summer. J. Vet. Intern. Med. 26(6):1413-1418. <http://dx.doi. org/10.1111/j.1939-1676.2012.00995.x><PMid:22946995>

Vick M.M., Adams A.A., Murphy B.A., Sessions D.R., Horohov D.W., Cook R.F. \& Fitzgerald B.P. 2007. Relationships among inflammatory cytokines, obesity, and insulin sensitivity in the horse. J. Anim. Sci. 85(5):1144-1155. <http:// dx.doi.org/10.2527/jas.2006-673><PMid:17264235>

Vick M.M., Murphy B.A., Sessions D.R., Reedy S.E., Kennedy E.L., Horohov D.W. \& Fitzgerald B.P. 2008. Effects of systemic inflammation on insulin sensitivity in horses and inflammatory cytokine expression in adipose tissue. Am. J. Vet. Res. 69(1):130-139. <http://dx.doi.org/10.2460/ ajvr.69.1.130><PMid:18167098>

Weber P.S.D., Schermerhorn K.N., McCutcheon L.J., Norby B., Burns T.A., Belknap J.K. \& Geor R.J. 2013. Adipokine, chemokine, and cytokine expression profiles in adipose tissue depots of lean and overweight ponies. J. Equine Vet. Sci. 33(10):846. <http://dx.doi.org/10.1016/j.jevs.2013.08.013>

Westervelt R.G., Stouffer J.R., Hintz H.F. \& Schryver H.F. 1976. Estimating fatness in horses and ponies. J. Anim. Sci. 43(4):781-785. <http://dx.doi. org/10.2527/jas1976.434781x>

Wyse C.A., McNie K.A., Tannahil V.J., Love S. \& Murray J.K. 2008. Prevalence of obesity in riding horses in Scotland. Vet. Rec. 162(18):590-591. <http:// dx.doi.org/10.1136/vr.162.18.590> <PMid:18453379>

Xavier V.F., Lima I.R., Marval C.A.D., Silveira D., Vieira R.A.M., Castro T.D.C., Moura D.A.D., Vilela S.B. \& Faleiros R.R. 2014. Estudo radiográfico do posicionamento da falange distal e suas possíveis correlações com obesidade em equinos de patrulhamento da Polícia Militar do Estado de Minas Gerais. Arq. Bras. Med. Vet. Zootec. 66(3):672-680. <http://dx.doi. org/10.1590/1678-41626006>

Young M.G., Tokach M.D., Aherne F.X., Main R.G., Dritz S.S., Goodband R.D. \& Nelssen J.L. 2004. Comparison of three methods of feeding sows in gestation and the subsequent effects on lactation performance. J. Anim. Sci. 82(10):3058-3070. <http://dx.doi.org/10.2527/2004.82103058x> $<$ PMid:15484959> 